\title{
Revolusi Pembelajaran dalam Matematika sebagai Konsekuensi dari Implementasi Physical Distancing
}

\author{
Faizatur Rofi'ah(1) \\ Muhammadiyah University of Surakarta \\ a410170034@student.ums.ac.id \\ Sutama(2) \\ Muhammadiyah University of Surakarta \\ sutama@ums.ac.id
}

DOI: 10.23917/varidika.v32i1.11386

Submission
Track:
Received:
29 Febuary 2020
Final Revision:
29 March 2020
Available online:
31 June 2020
Corresponding
Author:
Faizatur Rofi'ah(1)
a410170034@student.ums.ac.id
Sutama(2)

\begin{abstract}
The proliferation of the corona virus affects all aspects of life, including education. This led to a revolution in the learning from conventional to digital. The purpose of this study is to 1) describe the general review of learning in mathematics and; 2) analyzing the alternatives to the learning revolution in mathematics with the physical policy of physical distancing. This research uses type of reference research. The validity test uses source data triangulation. Data validity obtained with various sources and extensions. Data analysis techniques use constant methods of comparison. The result of this article, which is 1) in general, math learning has been more conventional (face to face) and; 2) there is an alternative to math related to physical distancing, which is online/long-distance learning by making good use of accessible applications through Internet service. Online math learning by giving both a learning video, the settings are as interesting as possible, online discussions, and assessments through online quizzes.
\end{abstract}

Keywords: mathematics, online learning in mathematics, physical distancing 


\section{PENDAHULUAN}

Pembelajaran merupakan kesempatan berpikir untuk mengevaluasi serta mencari kebenaran terhadap suatu informasi yang telah diperoleh sebelumnya. Hardiyana (2016) menyampaikan bahwa proses pembelajaran sesungguhnya memiliki peran penting dalam upaya meningkatkan kualitas pendidikan, sehingga pembelajaran yang diselenggarakan dapat membawa kebermaknaan dan kemanfaatan bagi pembelajar. Setiap pembelajaran tak luput dengan adanya matematika. Matematika merupakan ilmu pengetahuan yang sangat penting dan sangat berperan dalam ilmu pendidikan (Sutama et al., 2020). Dalam upaya meningkatkan sumber daya manusia yang berkualitas, matematika yang diberikan di sekolah menjadi sangat penting. Namun, sifat abstrak dari matematika menyebabkan peserta didik mengalami kesulitan dalam memahami konsep-konsep matematika (Pinahayu, 2016).

Proses pembelajaran yang optimal diperlukan untuk menunjang tercapainya tujuan matematika dalam pendidikan. Selama ini peserta didik lebih memahami materi ketika proses pembelajaran matematika berlangsung secara tatap muka sehingga diperoleh hasil akhir yang maksimal. Akan tetapi, seharusnya dalam pembelajaran matematika tidak hanya berorientasi pada hasil akhir, melainkan lebih menekankan pada proses selama kegiatan belajar mengajar berlangsung (Syahrir, 2016). Disamping itu, penguasaan matematika penting dalam usaha mengembangkan ilmu pengetahuan dan teknologi kedepannya.

Mewabahnya virus corona atau COVID-19 (Corona Virus diseases-19) yang memiliki kecepatan penyebaran tinggi dan belum adanya vaksin penyembuhan berdampak pada seluruh aspek kehidupan termasuk dunia pendidikan. Para peneliti di Imperial College di London, memperkirakan dampak global pada tahun 2020 berkisar antara 20 juta kematian dengan intervensi non-farmasi yang efektif dan 40 juta kematian tanpa intervensi (Walker et al, 2020). Sedangkan virus corona telah mawabah di Indonesia sejak awal Maret hingga saat ini 15 Juni 2020 terdapat 38.277 kasus positif terkonfirmasi yang tersebar di 34 provinsi dan 430 kabupaten/kota (Gugus Tugas Percepatan Penanganan COVID-19 Indonesia, 2020).

Berbagai kebijakan telah dikeluarkan oleh pemerintah untuk mengurangi tingkat penyebaran virus corona sebagai bentuk pencegahan. Adanya langkah-langkah pencegahan dalam bentuk social distancing, physical distancing hingga pemberlakuan PSBB (Pembatasan Sosial Berskala Besar) menjadi pendorong keselamatan. Dr. Jeff Kwong, spesialis penyakit menular dan profesor di Departemen Kedokteran Keluarga dan Komunitas di University of Toronto menyebutkan istilah physical distancing atau jarak fisik berarti benar-benar terpisah secara fisik, tetapi secara sosial tetap bersatu walaupun hanya dengan cara virtual $(2020,23$ Maret).

Kebijakan yang dikeluarkan berdampak hampir di seluruh aspek kehidupan. COVID19 menciptakan problem baru dalam pendidikan dan berpotensi mendorong inovasi pendidikan serta pembelajaran (Wahab, 2020). Hal inilah yang mendorong adanya perubahan atau revolusi dalam pembelajaran dari konvensional menjadi digital. Penggunaan teknologi digital dapat menjembatani saat langkah-langkah physical distancing sedang dilakukan (Galea, Merchant, \& Lurie, 2020). Selain itu, perkembangan dalam dunia teknologi saat ini memiliki pengaruh yang 
sangat signifikan terhadap sistem pendidikan. Perkembangan yang tampak nyata yaitu pada proses pembelajaran.

Pada tanggal 24 Maret 2020 Kementerian Pendidikan dan Kebudayaan Republik Indonesia mengeluarkan Surat Edaran Nomor 4 Tahun 2020 tentang Pelaksanaan Kebijakan Pendidikan dalam Masa Darurat Penyebaran COVID-19 yang menjelaskan bahwa proses belajar dilaksanakan dari rumah melalui pembelajaran daring/jarak jauh untuk memberikan pengalaman belajar yang bermakna bagi peserta didik. Metamorfosis ini membutuhkan adaptasi agar kegiatan belajar mengajar berjalan efektif. Adanya pembelajaran jarak jauh secara tidak langsung menuntut guru dan pendidik untuk beralih dari pembelajaran konvensional menjadi pembelajaran daring (online). Selain itu, kedisiplinan peserta didik saat belajar diharapkan menjadi modal bagi mereka untuk disiplin menjalankan pembatasan sosial. Selama pandemi, tsunami pembelajaran online telah terjadi hampir di seluruh dunia (Goldschmidt \& Msn, 2020). Pembelajaran online merupakan pembelajaran yang mempermudah kedua belah pihak karena materi ajar disampaikan secara daring (Simanihuruk et al., 2019).

Berdasarkan uraian tersebut, maka penulis menganggap bahwa perlu untuk melakukan kajian tentang revolusi pembelajaran khususnya pada pembelajaran matematika selama masa pandemi COVID-19. Hal ini bertujuan untuk 1) mendeskripsikan tinjauan umum terkait pembelajaran dalam matematika dan; 2) menganalisis alternatif revolusi pembelajaran dalam matematika dengan adanya kebijakan physical distancing.

\section{METODE PENELITIAN}

Penelitian ini menggunakan jenis penelitian referensi. Menurut Sutama (2019) penelitian referensi merupakan penelitian yang pengambilan datanya berorientasi pada beberapa referensi yang sesuai. Referensi yang digunakan meliputi berita, majalah, buku dan artikel-artikel pada jurnal online yang relevan dengan penelitian.

Objek dalam penelitian ini yaitu pembelajaran dalam matematika. Adanya masa pandemi mengubah pembelajaran yang mulanya secara langsung beralih menjadi pembelajaran jarak jauh. Pembelajaran jarak jauh atau daring merupakan pembelajaran yang dilakukan melalui media online yang dapat diakses menggunakan layanan internet.

Dalam uji validitas, peneliti menggunakan triangulasi sumber data. Keabsahan data dengan berbagai sumber dan perpanjangan waktu. Menurut Sutama (2019) triangulasi sumber artinya data diambil dari beberapa sumber dan diperoleh data yang sama. Sedangkan triangulasi perpanjangan waktu artinya data diperoleh dari waktu yang diulang-ulang dan berbeda sehingga diperoleh data sama yang sama.

Proses pengumpulan data dalam penelitian ini diperoleh melalui berita, majalah, buku dan artikel-artikel pada jurnal online. Teknik analisis data yang digunakan yaitu dengan metode komparasi konstanta. Menurut Sutama (2019) teknik analisis data dengan komparasi konstan adalah data dibandingan dengan teori-teori yang sesuai dan kemudian diberi makna. Proses analisis data dilakukan dengan 5 tahapan, antara lain 1) pengumpulan data; 2) reduksi data; 3) display/penyajian data; 4) verifikasi dan 5) simpulan. 


\section{HASIL DAN PEMBAHASAN}

\section{Mendeskripsikan tinjauan umum terkait pembelajaran dalam matematika}

Pendidikan merupakan salah satu sarana yang bertanggung jawab untuk mengatasi ketertinggalan yang ada. Peningkatan mutu pendidikan merupakan salah satu usaha untuk mencapai keberhasilan pendidikan suatu bangsa (Sutama et al., 2019). Pendidikan memiliki peran penting dalam mencetak sumber daya manusia yang berkualitas baik dari segi spiritual, intelegensi, maupun skill (Anisah \& Fajriah, 2019). Pendidikan juga merupakan sebuah sistem yang terdiri dari tujuan, metode, materi (kurikulum), pendidik, peserta didik, alat pendidikan dan lingkungan yang saling berhubungan. Sistem pendidikan nasional harus mampu meningkatkan mutu pendidikan, sebab pendidikan bertujuan mentransfer pengetahuan, tata nilai, dan kemampuan berpikir.

Salah satu cara mengembangkan kemampuan berpikir logis diperoleh melalui pembelajaran matematika. Adanya pembelajaran matematika di sekolah harus dapat membekali peserta didik untuk menghadapi tantangan perkembangan dan perubahan yang akan datang. (Harahap \& Fauzi, 2018) menjelaskan bahwa pembelajaran matematika merupakan proses interaksi antara guru dan peserta didik yang melibatkan pengembangan pola berpikir dan mengolah logika pada suatu lingkungan belajar yang sengaja diciptakan oleh guru dengan berbagai metode agar program belajar matematika tumbuh dan berkembang secara optimal serta peserta didik dapat melakukan kegiatan belajar secara efektif dan efisien.

Pembelajaran matematika haruslah bermakna. Gazali (2016) menjelaskan bahwa pembelajaran matematika yang bermakna bisa berarti belajar matematika tidak sekadar menghafal rumus-rumus untuk menyelesaikan suatu masalah matematika, melainkan melalui kegiatan yang menyenangkan. Pembelajaran dalam matematika menjadi bermakna hanya apabila diimplementasikan oleh pendidik yang dapat dengan cepat dan tepat dalam mengatasi kondisi apapun. Guru/pendidik bertanggung jawab atas proses belajar peserta didik dengan mengatur dan mengondisikan lingkungan belajar dimana guru/pendidik secara aktif dan inovatif mendukung peserta didik dalam pembelajaran matematika, dan peserta didik juga katif sendiri dalam belajar matematika (Narimo et al., 2018).

Sejauhmana ketercapaian matematika yang diajarkan bergantung pada bagaimana matematika diperajarkan kepada peserta didik. Selain harus mempu menguasai materi yang akan diajarkan, pendidik juga harus mampu memilih strategi pembelajaran matematika yang tepat. Kesuksesan atau kegagalan dalam pembelajaran matematika juga dipengaruhi oleh bahan ajar matematika yang diajarkan, pendidik yang memperajarkan matematika, dan peserta didik yang belajar matematika. Relevansi antara ketiga sangat erat sehingga harus dipenuhi dalam rangka menunjang pembelajaran dalam matematika. Keberhasilan dalam pembelajaran matematika harus didukung dengan pendidik yang mampu menyampaikan materi dengan cara apapun dan kondisi bagaimanapun.

Proses penyampaian materi dalam pembelajaran matematika sangat berpengaruh terhadap tingkat pemahaman peserta didik. Dalam pembelajaran matematika, guru/pendidik sebagai fasilitator juga harus memberikan pemahaman konsep yang benar kepada peserta didik. 
Guru/pendidik diharapkan mampu menciptakan kondisi yang dapat menunjang pemahaman peserta didik selama proses pembelajaran berlangsung. Pemilihan strategi, metode, maupun media pembelajaran yang digunakan haruslah disesuaikan dengan kondisi yang ada.

\section{Menganalisis alternatif revolusi pembelajaran dalam matematika dengan adanya physical distancing}

Upaya pemerintah untuk membatasi perkumpulan dalam rangka memutus rantai penyebaran COVID-19 dengan mengeluarkan kebijakan physical distancing. Kebijakan ini tentu menimbulkan berbagai dampak disetiap aspek kehidupan baik dari segi positif maupun negatif. Lingkungan pendidikan turut serta mendukung kebijakan physical distancing. Sesuai dengan anjuran Pemerintah, maka Kemendikbud mengeluarkan kebijakan agar peserta didik "belajar dari rumah" dengan memanfaatkan layanan internet. Kebijakan Kemendikbud yaitu dengan menggalakan pembelajaran daring/jarak jauh (SFH/Study From Home). Kebijakan tersebut diberlakukan bagi sekolah maupun perguruan tinggi. Diberlakukannya pembelajaran daring/jarak jauh sangat berpengaruh terhadap kompetensi pendidikan, terutama dalam penggunaan strategi, metode, dan media pembelajaran.

Pembelajaran jarak jauh menjadi solusi terbaik guna tetap menjalankan roda pendidikan di Indonesia. Peralihan pembelajaran konvensional menjadi pembelajaran daring/jarak jauh diperlukan perhatian khusus dari para pendidik guna mencari dan mengembangkan strategi, metode, dan media pembelajaran matematika yang dapat mengakomodasi kemampuan peserta didik. Pembelajaran daring (online) perlu mengatur ulang ujian dan tugas rumah ke prinsip buku terbuka yang tidak dikembangkan dan populer sebelum-sebelumnya. Adanya proses digital mengakibatkan lembaga pendidikan menghadapi sebuah perubahan yang sangat signifikan. Selain menjadi peluang dan cara untuk meningkatkan kualitas pendidikan juga sekaligus menjadi tantangan bagi dunia pendidikan di Indonesia (2017, 23 Desember).

Pembelajaran jarak jauh dapat diantisipasi melalui pemanfaatan teknologi. Pemanfaatan sumber daya teknologi sebagai media dalam proses pembelajaran merupakan maksud dari adanya penggunaan teknologi dalam pembelajaran (Akhmadan, 2017). Dalam pengembangan pendidikan nasional, penerapan informasi dan teknologi menjadi sesuatu yang wajib. Semakin banyaknya pengguna teknologi dalam dunia pendidikan akan mengakibatkan perubahan model pembelajaran (2020, 2 April). Selama pembelajaran guru harus mampu memanfaatkan teknologi informasi dengan menggunakan metode yang menyenangkan, memperkaya keilmuan dengan berbagai sumber bacaan, dan mampu melakukan penelitian (Barni, 2019).

Perkembangan teknologi sangat berdampak bagi dunia pendidikan. Teknologi yang berkembang pesat dapat dimanfaatkan untuk memaksimalkan proses pembelajaran. Media berperan penting dalam proses penyampaian materi agar mudah diterima oleh peserta didik secara maksimal (Wicaksono, 2016). Media pembelajaran berbasis teknologi yang sering digunakan saat pembelajaran jarak jauh yaitu komputer dan smartphone. Pendidik dituntut untuk harus mengikuti perkembangan teknologi dan tidak diperbolehkan gagap teknologi. Selain itu, untuk menghindarkan peserta didik dari penyalahgunaan teknologi, maka pendidik juga harus memahami betul konsekuensi penerapan teknologi dalam dunia pendidikan. Peserta didik yang mayoritas paham teknologi tidak akan meremehkan seorang guru maupun pendidik yang mampu mengikuti arus perkembangan teknologi. 
Dalam pembelajaran matematika, guru/pendidik dapat memanfaatkan teknologi untuk memperkaya materi maupun metode pembelajaran. Adanya peningkatan kualitas pembelajaran juga didukung dengan guru melakukan pengembangan dari sebuah media pembelajaran (Masykur et al., 2017). Teknologi yang berkembang pesat semakin menambah banyaknya pilihan bahan ajar dan sumber belajar seperti perpustakaan elektronik (e-library), buku elektronik (e-book), jurnal elektronik (e-jounal), forum diskusi online (e-forum) dan sebagainya. Sehingga terbukti bahwa memungkinkan untuk tercipta lingkungan belajar yang menempatkan peserta didik yang dikelilingi oleh berbagai layanan dan sumber belajar elektronik yang lebih canggih.

Penggunaan teknologi yang semakin maju dalam pembelajaran matematika juga semakin mendukung pembelajaran jarak jauh (distance learning) yang sedang digalakan oleh pemerintah. Materi matematika yang dianggap membosankan oleh peserta didik mendorong adanya perubahan pada penampilannya. Penyusunan materi atau bahan ajar agar lebih dinamis dan menarik dapat di setting menggunakan aplikasi komputer maupun smartphone dengan efektif. Selanjutnya bahan ajar tersebut divirtualisasikan ke dalam format pembelajaran untuk dapat di unggah dan di unduh oleh peserta didik. Bahan ajar yang dibuat sedemikian rupa dapat menambah motivasi peserta didik dalam proses pembelajaran matematika secara daring (online).

Adanya komputer, smartphone, dan layanan internet yang mendukung dapat digunakan peserta didik untuk mengakses materi pelajaran yang akan disampaikan. Berbagai aplikasi telah diciptakan guna mendukung pendidikan secara daring di seluruh belahan dunia bahkan sebelum adanya pandemi COVID-19. Aplikasi yang dapat dimanfaatkan selama pembelajaran daring/jarak jauh seperti google classroom, google meet, zoom, schoology, edmodo, ruangguru, YouTube, dan masih banyak lagi. Sehingga kedepannya peserta didik tidak hanya pasif dengan membaca materi yang telah diberikan, namun lebih aktif dan dapat mencoba hal baru yang lebih canggih dari apa yang telah diberikan guru/pendidik sebelumnya (Syaf, Kariadinata, \& Widiastuti, 2020).

Dalam proses pembelajaran matematika, pemberian materi bahan ajar saja tidaklah cukup untuk mencapai tujuan diajarkannya matematika. Diperlukan aksi nyata dari guru maupun pendidik dalam menyampaikan materi selama proses pembelajaran matematika. Guru/pendidik dapat membuat video kreatif yang lebih memudahkan peserta didik memahami konsep matematika meskipun dengan pembelajaran jarak jauh. Video pembelajaran tersebut berisi suatu bab atau materi yang akan disampaikan. Penelitian yang telah dilakukan sebelumnya menunjukkan bahwa penggunaan video tutorial di masa pandemi dapat melengkapi sarana pembelajaran daring. Video tutorial dapat digunakan sebagai bahan diskusi, bahan praktek, dan untuk meningkatkan pemahaman terhadap materi yang disampaikan melalui pertemuan daring (Batubara \& Batubara, 2020).

Video pembelajaran dalam matematika tersebut dapat diunggah melalui platform YouTube ataupun video conference lainnya. Guru/pendidik hanya perlu memberi tahu peserta didik untuk mengujungi laman yang bersangkutan. Selain melihat video pembelajaran, peserta 
didik dipersilakan untuk mengunduh video tersebut. Video pembelajaran yang telah diunduh memungkinkan peserta didik untuk memutarnya berulang ketika kesulitan memahami suatu $\mathrm{bab} /$ materi matematika secara mandiri. Hal ini berdampak positif terhadap tingkat pemahaman peserta didik pada konsep matematika yang sedang dipelajari. Sehingga kedepannya diharapkan pembelajaran matematika secara daring tetap berjalan maksimal seperti ketika pembelajaran secara konvensional (tatap muka).

Selain pemberian materi atau bahan ajar menggunakan video kreatif kepada peserta didik secara online, penyampaian materi secara langsung (tatap muka) juga dapat dilakukan dalam jaringan. Guru/pendidik dan peserta didik dapat menggunakan aplikasi bernama google meet dan zoom secara kolektif. Menjadwalkan pertemuan secara daring dengan peserta didik, kemudian guru/pendidik menyampaikan materi matematika yang akan dipelajari saat itu. Guru/pendidik dapat menjelaskan sebagaimana menjelaskan materi matematika ketika berada di kelas. Pembelajaran matematika dengan menggunakan video conference tersebut juga dapat direkam. Rekaman video selama pembelajaran juga dapat dibagikan kepada peserta didik ketika telah selesai. Hal ini tentu semakin mendukung pembelajaran matematika secara daring, serta mampu menjadi upaya untuk meningkatkan pemahaman konsep matematika peserta didik.

Pembelajaran matematika juga tak luput dengan adanya diskusi. Diskusi yang biasa dilakukan secara berkelompok di kelas, kini juga dilakukan dalam jaringan. Diskusi dalam jaringan dapat dilakukan melalui diskusi online. Seperti fasilitas pada penggunaan aplikasi schoology. Guru/pendidik membuat sebuah akun kemudian bergabung dalam suatu kelas online pada schoology. Terdapat ruang diskusi yang memungkinkan guru/pendidik maupun peserta didik melakukan diskusi dengan cara memberikan pendapatnya melalui kolom komentar. Peserta didik yang memberikan pendapat tersebut dapat langsung ditanggapi oleh guru maupun peserta didik lainnya sehingga memungkinkan adanya pembelajaran matematika yang aktif meskipun jarak jauh/dalam jaringan.

Penilaian selama proses pembelajaran matematika juga turut serta melengkapinya. Pemberian nilai yang awalnya secara tertulis maupun lisan, kini dapat dilakukan secara online. Guru/pendidik dapat memberikan penilaian melalui kuis dalam sebuah aplikasi. Aplikasi yang biasa digunakan yaitu google form dengan cara peserta didik menjawab pertanyaan yang telah disediakan. Di akhir pengerjaan, jawaban tersebut diunggah dan peserta didik dapat langsung mengetahui perolehan nilainya. Bahkan, ujian dengan menggunakan aplikasi juga telah memudahkan guru maupun peserta didik karena adanya kebijakan physical distancing. Masalah penilaian adalah aktual ketika peserta didik tinggal di luar sekolah dan teknologi baru harus dipertimbangkan untuk anti-plagiarisme dan menghindari kecurangan (Basilaia \& Kvavadze, 2020).

Pembelajaran matematika maupun pembelajaran yang lainnya secara daring dapat berjalan lancar apabila fasilitas juga terpenuhi. Ferdiansyah anggota DPR Jawa Barat menyampaikan kepada Kemendikbud bahwa masih terdapat daerah yang belum teraliri listrik dengan baik (2020, 20 Mei). Adanya listrik, juga dibutuhkan komputer maupun smartphone yang memadai. Selanjutnya juga dibutuhkan layanan internet yang juga harus mendukung. Aplikasi yang ada mudah untuk diakses akan tetapi juga mengalami kesulitan terhubung ke 
jaringan internet, sehingga peserta didik terkendala saat harus tetap berada di kelas online (Novita \& Hutasuhut, 2020). Harga kuota internet juga memengaruhi kelancaran pembelajaran online. Hal ini menjadi hambatan dalam implementasi pembelajaran jarak jauh yang menjadi kebijakan saat ini. Sehingga diperlukan perhatian serius dari Pemerintah.

\section{SIMPULAN}

Pembelajaran dalam matematika mengalami revolusi sebagai bentuk dari adanya implementasi physical distancing. Secara umum, pembelajaran dalam matematika selama ini lebih banyak berlangsung secara konvensional (tatap muka). Namun kini terdapat alternatif terkait pembelajaran dalam matematika sebab adanya kebijakan physical distancing, yaitu pembelajaran jarak jauh dengan memanfaatkan aplikasi yang diakses melalui layanan internet. Pembelajaran dalam matematika secara daring dengan cara memberikan video pembelajaran maupun video conference, materi di setting semenarik mungkin, diskusi online, dan penilaian melalui kuis online. Penerapan pembelajaran matematika secara daring mampu berkontribusi dalam rangka meningkatkan kemampuan pemahaman konsep matematika pada peserta didik. Pembelajaran dalam matematika melalui aplikasi masih membutuhkan inovasi terus-menerus dari guru/pendidik maupun Pemerintah.

Pada kesempatan ini, terdapat beberapa ucapan terima kasih kepada berbagai pihak yang telah mendukung kegiatan penilitan ini. Ucapan terima kasih penulis sampaikan pada DEKAN FKIP UMS beserta jajarannya, atas izin perkuliahan ini sehingga dapat berjalan sesuai harapan. Ucapan terima kasih juga penulis ucapkan kepada Pimpinan Program Studi Pendidikan Matematika FKIP UMS beserta seluruh dosen yang telah membimbing penulis dan memberikan fasilitas serta dorongan sehingga dapat belajar sesuai yang diharapkan.

\section{REFERENSI}

Akhmadan, W. (2017). Pengembangan Bahan Ajar Materi Garis dan Sudut Menggunakan Macromedia Flash dan Moodle Kelas VII Sekolah Menengah Pertama. Jurnal Gantang, 2(1), 27-40. Retrieved from https://doi.org/10.31629/jg.v2i1.62

Anisah, H. \& Fajriah, N. (2019). Meningkatkan Minat Belajar Siswa SMA dalam Pembelajaran Matematika melalui Penerapan Model Pembelajaran ARIAS. SENPIKA II: Seminar Nasional Pendidikan Matematika.

Baihaqi, B. (2017, 23 Desember). Pendidikan dan Digitalisasi di Era Milenial. E-paper: Harian Ekonomi Neraca. Retrived from https://www.neraca.co.id/article/94700/pendidikan-dandigitalisasi-di-era-milenial

Barni, M. (2019). Tantangan Pendidik Di Era Millennial. Transformatif, 3(1), 99-116. Retrieved from https://doi.org/10.23971/tf.v3i1.1251

Basilaia, G. \& Kvavadze, D. (2020) Transition to Online Education in Schools during a SARSCov-2 Coronavirus (COVID-19) Pandemic in Georgia. Pedagogical Research, 5(4), 3m0060. Retrieved from https://doi.org/10.29333/pr/7937

Batubara, H. H., \& Batubara, D. S. (2020). Penggunaan Video Tutorial Untuk Mendukung Pembelajaran Daring Di Masa Pandemi Virus Corona. Muallimuna : Jurnal Madrasah 
Ibtidaiyah, 5(2), 21. Retrieved from https://doi.org/10.31602/muallimuna.v5i2.2950

Etrina, Anriani, N., \& Fathurrohman, M. (2019). Pengembangan Bahan Ajar Matematika berbasis Kompetensi Abad 21 untuk Guru SMP/MTs. Prosiding Seminar dan Diskusi Nasional Pendidikan Dasar.

Galea, S., Merchant, R. M., \& Lurie, N. (2020). The Mental Health Consequences of COVID19 and Physical Distancing: The Need for Prevention and Early Intervention. JAMA Internal Medicine, 180(6), 817.

Gazali, R. Y. (2016). Pembelajaran Matematika Yang Bermakna. Math Didactic: Jurnal Pendidikan Matematika, 2(3), 181-190. Retrieved from ttps://doi.org/10.33654/math.v2i3.47

Goldschmidt, K., \& Msn, P. D. (2020). The COVID-19 pandemic : Technology use to support the wellbeing of children. Journal of Pediatric Nursing, xxx, 3-5. Retrieved from https://doi.org/10.1016/j.pedn.2020.04.013

Gugus Tugas Percepatan Penanganan COVID-19 Indonesia. (2020). Data COVID-19 Global dan Indonesia. Retrieved from https://covid19.go.id/

Harahap, M. S., \& Fauzi, R. (2018). Pengembangan Modul Pembelajaran Matematika Berbasis Web. Jurnal Education and Development, 4(5), 13. Retrieved from https://doi.org/10.37081/ed.v4i5.153

Hardiyana, A. (2016). Optimalisasi Pemanfaatan Teknologi Informasi dan Komunikasi dalam Pembelajaran PAUD. AWLADY: Jurnal Pendidikan Anak, 2(1), 1-12. Retrieved from https://badge.dimensions.ai/details/doi/10.24235/awlady.v2i1.762.g603?domain=http://s yekhnurjati.ac.id

Hensley, L. (2020, 23 Maret). Social distancing is out, physical distancing is in - here's how to do it. Global News. Retrieved from https://globalnews.ca/news/6717166/what-isphysical-distancing/

Kementerian Pendidikan dan Kebudayaan. (2020). Mendikbud Terbitkan SE tentang Pelaksanaan Pendidikan dalam Masa Darurat COVID-19. Retrieved from https://www.kemdikbud.go.id/main/blog/2020/03/mendikbud-terbitkan-se-tentangpelaksanaan-pendidikan-dalam-masa-darurat-covid19

Masykur, R., Nofrizal, N., \& Syazali, M. (2017). Pengembangan Media Pembelajaran Matematika dengan Macromedia Flash. Al-Jabar : Jurnal Pendidikan Matematika, 8(2), 177. Retrieved from https://doi.org/10.24042/ajpm.v8i2.2014

Narimo, S., Hastuti, D. D., \& Sutopo, A. (2018). Konsekuensi Tanggung Jawab dalam Pembelajaran Matematika SMA. Jurnal VARIDIKA, 30(2), 1-6. Retrieved from http://doi.org/10.23917/varidika.v30i2.7568

Nur, M. (2020, 20 Mei). Banyak Daerah Tidak Terjangkau Internet, Ferdianyah Minta Kemendikbud Lakukan Pemetaan. Pikiran Rakyat. Retrieved from https://jurnalgarut.pikiran-rakyat.com/pendidikan/pr-33392304/banyak-daerah-takterjangkau-internet-ferdiansyah-minta-kemendikbud-lakukan-pemetaan 
Pinahayu, E. A. R. (2016). Problematika Pembelajaran Matematika pada Pokok Bahasan Eksponen dan Alternatif Pemecahannya. Formatif: Jurnal Ilmiah Pendidikan MIPA, 5(3), 182-191. Retrieved from https://doi.org/10.30998/formatif.v5i3.642

Setiabudi, D. (2020, 2 April). Nadiem Makarim: Sebuah Tantangan Pendidikan Millennial. Majalah Al Azhar, Edisi 302. Retrieved from https://fliphtml5.com/ccsjy/agce/basic

Simanihurul, L., Simarmata, J., Sudirman, A., Hasibuan, M. S., Safitri, M., Sulaiman, O. K., ... \& Sahir, S. H. (2019). E-Learning: Implementasi, Strategi, dan Inovasinya. Yayasan Kita Menulis

Sutama. (2019). Metode Penelitian Pendidikan (Kuantitatif, Kualitatif, PTK, Mix Method, $R \& D)$. Sukoharjo: Jasmine

Sutama, Hartini, S., \& Novitasari, M. (2019). Kemandirian dalam Pembelajaran Matematika di Madrasah Tsanawiyah. Jurnal VARIDIKA, 30(2), 7-14. Retrieved from https://doi.org/10.23917/varidika.v30i2.7569

Sutama, S., Sofia, S., \& Novitasari, M. (2020). Analisis Kemampuan Penyelesaian Soal Matematika Berorientasi Pisa Dalam Konten Perubahan Dan Hubungan Pada Siswa Smp. Jurnal VARIDIKA, 31(2), 29-36. Retrieved from https://doi.org/10.23917/varidika.v31i2.10216

Syaf, A. H., Kariadinata, R., \& Widiastuti, T. (2020). Self Regulated Learning Mahasiswa pada Implementasi Pembelajaran Daring Mata Kuliah Kalkulus Vektor.

Syahrir. (2016). Pengembangan Perangkat Pembelajaran Matematika SMP untuk Meningkatkan Kemampuan Berfikir Kreatif. Jurnal Ilmiah Mandala Education (JIME), 2(1).

Wahab, R. (2020). Pendidikan Era Covid-19 oleh Rektor Universitas Negeri Yogyakarta (UNY) Periode 2009-2017. Times. Retrieved from https://www.timesindonesia.co.id/read/news/266030/pendidikan-era-covid19

Walker, P. G. T., Whittaker, C., Watson, O., et al. (2020). The Global Impact of COVID-19 and Strategies for Mitigation and Suppresion. Imperial College London. Retrieved from https://doi.org/10.25561/77735

Wicaksono, S. (2016). The Development Of Interactive Multimedia Based Learning Using Macromedia Flash 8 In Accounring Course. Journal of Accounting and Business Education, 1(1), 122-139. 